\title{
Regional Projection of Environmental Consequences of Crises in the Russian Economy
}

\author{
V. R. Bityukova* \\ Moscow State University, Faculty of Geography, Moscow, 119991 Russia \\ *e-mail: v.r.bityukova@geogr.msu.ru \\ Received September 26, 2021; revised October 5, 2021; accepted October 7, 2021
}

\begin{abstract}
The influence of economic crises in the post-Soviet history on the state of the environment is manifested in different directions and unevenly across regions. During crises, the dependence of pollution indicators on changes in GDP (GRP) and industrial production is higher than during periods of economic growth. During crisis years, there was a decrease in industrial pollution, the volume of atmospheric emissions and polluted wastewater, and, to a lesser extent, water consumption; conversely, vehicle emissions, the volume of toxic waste, the area of disturbed lands, and forest fires do not depend on the change in GRP. Only specific pollution parameters increase during crises. The integral index of anthropogenic impact depends less on the GRP dynamics than some indicators of the load on the natural environment. With a general trend towards a decrease in environmental stress, the group of regions with a critical level of impact is characterized by the greatest stability, while the group of regions with an insignificant level of pressure on the natural environment contracts. Differences in the sanitizing role of crises are due to their duration, depth, and structural features, as well as the mitigating effect of government support measures. The systemic crisis of the 1990s led to a reduction in all indicators, affecting 90\% of regions, while the financial crises of 1998 and 2008-2009 affected $70 \%$ of regions, and the crises of 2014-2015 and 2020, 30-60\%. Despite the fact that for the country as a whole, the dependence of the level of pollution on the level and dynamics of economic development is weakening, with each new crisis, there is an increasing number of regions where the environmental state continues to deteriorate despite the economic downturn.
\end{abstract}

Keywords: ecological and economic analysis, pollution indicators, integral index, anthropogenic impact, Russia, regions

DOI: $10.1134 / \mathrm{S} 2079970521040213$

\section{INTRODUCTION AND FORMULATION OF THE PROBLEM}

The consequences of economic crises are studied in the social, economic, psychological, and philosophical planes. In the field of crisis manifestations, special attention is paid to identifying the sources, root causes, and destructive trends, assessing the crisis phenomena themselves and finding active paths out them and overcome the consequences, including environmental. An economic crisis can give rise to the illusion of decreasing pressure on the environment. The recent crisis has led to a rethinking of many phenomena and an increase in requirements on the environment. However, a decrease in GDP does not directly correlate with a decrease in the environmental load and environmental degradation: the volumes of extracted fuel and energy resources and the magnitude of the environmental pressure of the fuel and energy complex decrease slightly, investment in environmental protection and the degree of control decrease, accidents increase, waste management projects are inhibited, and forest fires spread.
The impact of crises on the environmental state is multidirectional and has its own regional projection. It is reflected in different ways by individual indicators of anthropogenic impact and the integral index of environmental stress. The economic and geographical approach to studying the environmental problems of territories is based on comprehensive analysis and assessment of their causes, an important place among which is occupied by the dynamics and structural transformations in material production.

\section{REVIEW OF EARLIER STUDIES}

The problems of the influence of economic dynamics on the environmental situation were touched upon in works by many economists, ecologists, and geographers. Criticism of the negative tendencies of Western civilization dominating the scientific and public discourse of the 1970s and debunking of the technocratic myth of economic growth as the most effective means of solving all problems were gradually supplanted by the idea of the optimum level 
of economic development, for which environmental damage will be minimal. In such a situation, the Kuznets curve was proposed for use in environmental policy (Grossman and Krueger, 1991; Yandle et al., 2002). It became clear that it is possible to minimize the negative impact on nature with economic growth, since as wealth accumulates, the structure of the factors of pressure on the environment changes, the demand for environmentally friendly products increases, and the requirements on the environment increase (Gómez-Calvet et al., 2014; Lopez, 1994) as well as the fact that a true ecological crisis arises in conditions of poverty rather than abundance (Hollander, 2003).

In empirical studies, measurement and assessment of environmentally oriented development always include two diametrically opposing types of indicators (economic dynamics and negative environmental impacts), most of which reduce to three types of combinations:

(1) Both blocks of indicators are equal, and the quality of modern development is considered at the intersection of the coordinates of economic and environmental indicators: e.g., in the GAIN-Index, ${ }^{1}$ this is the relation of the country's vulnerability to global problems, combined with its willingness to increase resilience.

(2) One block is considered in functional dependence on another: modeling of the development of systems (enterprises, regions, countries) using growth variables as the desirable ones [the growth indicators are GDP (Rashidi et al., 2015; Wang et al., 2013; Wang et al., 2012), value added in industry (Shi et al., 2010), energy production and consumption (Gómez-Calvet et al., 2014 )], and variable negative externalities $-\mathrm{CO}_{2}$ and, less frequently, $\mathrm{SO}_{2}$ emissions (as an indicator of fuel oil consumption).

(3) The indicators of ecological cost are integrated into the economic growth indices: new macroeconomic indicators that neutralize the disadvantages of traditional ones, i.e., taking into account environmental impacts; e.g., the adjusted net savings index includes broader accounting for human capital and environmental factors (Stiglitz et al., 2020; Where ..., 2020).

Russian authors mainly consider the cost of economic growth (Artyukhov et al., 2012; Bobylev et al., 2012; Lopatnikov, 2013; Zemtsov et al., 2020; etc.). The environmental impact of a crisis is rarely studied. S.N. Bobylev and V.M. Zakharov (2009) note the ambiguity of the impact of crises on the environment. The negative environmental consequences of a crisis are associated with priority reduction in spending on environmental needs, a slowdown in structural and technological restructuring of the economy in favor of resource-saving innovative industries and activities,

\footnotetext{
${ }^{1}$ https://gain-new.crc.nd.edu/.
}

and a reduction in the cost of raw materials and energy, which undermines incentives to save them, as well as an increase in poaching. Conversely, new opportunities amid the crisis are associated with the withdrawal of the most obsolete assets, a slowdown in the expansion of nature-exploiting companies into hard-to-reach and ecologically pure areas, the ability to prevent the implementation of megaprojects, and reduce environmental pollution associated with production.

Strengthening of the role of the state in crises conditions in the implementing environmental policy seems ambiguous. The ideas of active state regulation formulated by the Keynesian economic school had a significant impact on the first stages in creating state environmental policy. There were recommendations for public works on landscaping and nature conservation during periods of recession and crisis with the involvement of unemployed people, to involve young people in landscaping work.

In Russia, the environmental friendliness of crisis phenomena was assessed in a regional analysis of anthropogenic impact under the influence of structural changes in the economy during the transition period (Bobylev et al., 2015; Klyuev, 2014). However, measurement of the environmental situation was considered, using individual indicators of the volume of emissions, effluents, relative to the economic dynamics and energy consumption (Artyukhov et al., 2015), without using integral estimates characterizing the situation as a whole.

\section{MATERIALS AND METHODS}

The integral (aggregated) indicators of anthropogenic impact (AI) correspond the most to the objectives of ecological and economic regional analysis. The integral AI index (IAI) was calculated by the methodology previously tested for Russia and countries of the post-Soviet space and including normalized indicators, the choice of which was justified in previous studies (Bityukova, 2017). One criterion for choosing the indicators was their availability in open official statistics published by federal structures, which avoids controversial indicators, which require special studies to calculate. Another criterion was their comparability over the study period; if it was impossible to exclude an indicator, a change in the methodology for its calculation was taken into account when interpreting the results.

To assess the dynamics of the environmental situation in regions for 1990-2020, certain changes were made to the methodology. First, the indicators were normalized, not with respect to the maximum and minimum values of a particular year, but with orientation towards stable reference points in order to track the dynamics of real growth/decline in AI for each indicator and in general. In terms of share, the range 
Table 1. Reference points and polar values of indicators, 1990-2020

\begin{tabular}{|c|c|c|c|c|}
\hline \multirow{2}{*}{ Indicator and information source } & \multicolumn{2}{|c|}{ Reference points } & \multicolumn{2}{|c|}{ Regional differences } \\
\hline & $\max$ & $\min$ & $\max$ & $\min$ \\
\hline$A_{1}$. Emission density, $\mathrm{t} /$ ha of industrial, transport, and other land & 10 & 0 & 8.5 & 0.05 \\
\hline $\begin{array}{l}A_{2} \text {. Toxicity factor (ratio of volume of emissions of all pollutants, taking into account their } \\
\text { toxicity to gross emission of region), calculated according to several sources } *, * *, * * *\end{array}$ & 83.2 & 6.82 & 100 & 1 \\
\hline$B_{1}$. Share of used water from the resources of river runoff, $\% * * * *, * * * * *$ & 82 & 0 & 68 & 0.01 \\
\hline$B_{2}$. Specific wastewater discharge per unit of river runoff resources, $\% \% * * * *, * * * * *$ & 27 & 0 & 22.6 & 0.09 \\
\hline$B_{3}$. Share of polluted wastewater, $\% * * * *, * * * * *$ & 100 & 0 & 98 & 10 \\
\hline$C_{1}$. Density of toxic waste disposal per industrial land area, $\mathrm{t} / \mathrm{ha}{ }^{*}, * * * * * *$ & 17 & 0 & 14 & 0.06 \\
\hline$C_{2}$. Share of disturbed lands, $\% *, * *, * * * *, * * * * * *$ & 5 & 0 & 4.3 & 0.10 \\
\hline$D_{1}$. Share of farmland, $\% *$ & 100 & 0 & 87 & 0.01 \\
\hline$D_{2}$. Share of arable land in area of farmland, $\% *, * * * * * * *$ & 100 & 0 & 88.5 & 0.10 \\
\hline$D_{3}$. Livestock density (conventional head without poultry per 1 ha of pasture) $*, * * * * * * *$ & 716 & 40 & 597 & 0.27 \\
\hline$D_{4}$. Mineral fertilizers (in terms of $100 \%$ nutrients), $\mathrm{kg} / \mathrm{ha}$ of crops $* * * * * * *$ & 280 & 2 & 234 & 2.6 \\
\hline$D_{5}$. Organic fertilizers, $\mathrm{t} / \mathrm{ha}$ of crops $* * * * * * *$ & 45 & 0 & 38 & 0.10 \\
\hline$D_{6}$. Share of reclaimed land, $\%$ of crops $*, * * * * * * *$ & 20 & 0 & 17 & 0.17 \\
\hline$D_{7}$. Volume of pesticide application, $\mathrm{kg} / \mathrm{ha}^{*}, * * * * * * * *$ & 45 & 0 & 37.5 & 0 \\
\hline$E_{1}$. Share of forests that died from diseases and burning, $\% *, * * * * * * * * *$ & 10 & 0 & 8.47 & 0.004 \\
\hline$E_{2}$. Volume of harvested timber, $\%$ of total standing timber**, ***, ********* & 8 & 0 & 6.4 & 0.01 \\
\hline $\begin{array}{l}E_{3} . \text { Share of illegal logging from stock, } \% \text {, calculated according to several } \\
\text { sources } *, * *, * * *, * * * * * * * * *)\end{array}$ & 0.62 & 0 & 0.52 & 0 \\
\hline
\end{tabular}

* Database of the Federal Service of State Registration, Cadastre and Cartography (Rosreestr); ** Okhrana okruzhayushchei sredy v Rossii: Statisticheskii sbornik (Environmental Protection in Russia: Statistical Handbook), Moscow: Goskomstat Ross., 2001, 2006, 2008, 2010, 2012, 2014, 2016, 2018, 2020; *** Osnovnye pokazateli okruzhayushchei sredy: statisticheskii byulleten' (Key Environmental Indicators: Statistical Bulletin), Moscow: Fed. Sluzhba Gos. Stat., 1997, 1999, 2003, 2005, 2007, 2009, 2011, 2013, 2015, 2017, 2019, 2021; **** Database of the Federal Agency of Water Resources. http://voda.mnr.gov.ru/doc_1139918730234. Accessed July 2, 2021; ***** Gosudarstvennyi doklad "O sostoyanii i ispol'zovanii vodnykh resursov Rossiiskoi Federatsii v 2008-2020 gg." (The Governmental Report On the State and Use of Water Resources of Russian Federation in 2008-2020), Moscow: Mineral-Info, $2009-2020$. https://www.mnr.gov.ru/docs/gosudarstvennye_doklady/o_sostoyanii_i_ispolzovanii_vodnykh_resursov_rossiyskoy_federatsii/. Accessed May 10, 2021; ****** Database of the Federal Supervisory Natural Resources Management Service (Rosprirodnadzor). http://rpn.gov.ru/opendata. Accessed July 8, 2021; ******* Main indicators of agriculture in Russia, 2021. http://www.gks.ru/wps/wcm/connect/rosstat_main//statistics/publications/catalog/doc_1140096652250. Accessed July 11, 2021; ******** Gosudarstvennyi doklad "O sostoyanii i ob okhrane okruzhayushchei sredy v Rossiiskoi Federatsii (The Governmental Report On the State and Protection of Environment in Russian Federation), Moscow, 2006-2020. http://www.ecogosdoklad.ru/. Accessed May 10, 2021; ********* Database of the Federal Forestry Agency, Unified Interdepartmental Statistical Information System (UISIS). https://www.fedstat.ru/indicator/37850. Accessed July 10, 2021.

from 0 to $100 \%$ was used. For indicators that do not have a maximum, taking into account the fact that most of them have a tendency to decrease, the maximum and minimum values for the period (19902020 ), increased and decreased by $20 \%$, were taken as the reference points (Table 1). Thus, the regions were distributed in the range of fixed, but unattainable values in the period under review. In case of extremely high differences, which distort the final index, in international comparisons, a discounting or logarithm procedure is used.
The second difference between the methodology used for comparison with the dynamics of GRP and industrial production in times of crisis is exclusion from the integral index of indicators of the radiation situation, since this type of pollution is to a greater extent a consequence of accidents of an earlier period, not of modern functioning of the nuclear fuel cycle.

The integral IAI was calculated as the sum of averages for blocks (types of impact) according to the formula (notation of indicators is given in table above): 


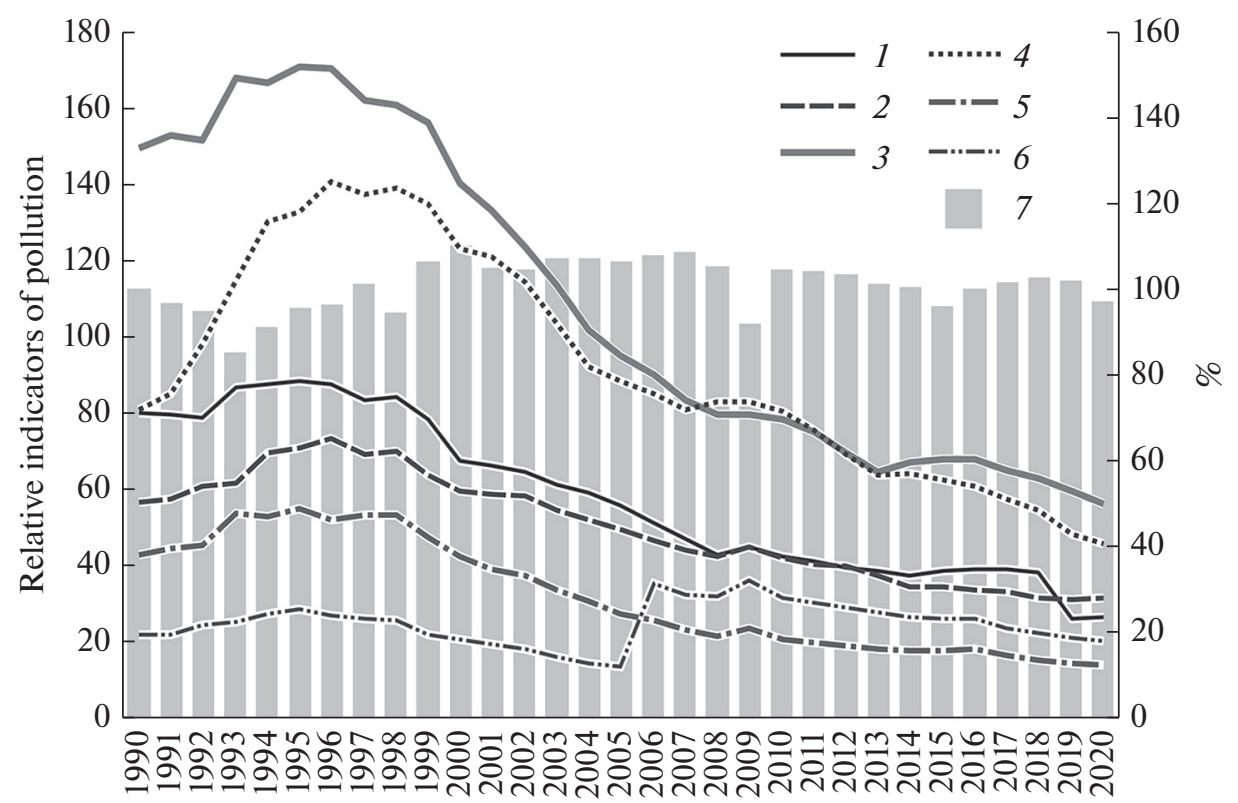

Fig. 1. Dynamics of specific pollution indicators, 1990-2020. Left scale: 1, total emissions in relation to GDP, kg/1000 RUB, in 1990 prices; 2 , industrial emissions in relation to industrial output, $\mathrm{kg} / 1000 \mathrm{RUB}$, in 1990 prices; 3 , water consumption in relation to GDP, 1/RUB; 4, industrial water consumption in relation to industrial output, $1 / \mathrm{RUB} ; 5$, polluted wastewater in relation to GDP), 1/RUB; 6 , industrial polluted wastewater in relation to industrial output, 1/RUB; right scale: 7, GDP, \% to previous year.

$$
\begin{aligned}
\mathrm{IAI}= & \left(\left(\frac{A_{1}+A_{2}}{2}\right)+\left(\frac{B_{1}+B_{2}+B_{3}}{3}\right)+\left(\frac{C_{1}+C_{2}}{2}\right)\right. \\
+ & \left(\frac{D_{1}+D_{2}+D_{3}+D_{4}+D_{5}+D_{6}+D_{7}}{7}\right) \\
& \left.+\left(\frac{E_{1}+E_{2}+E_{3}}{3}\right)\right) / 5 .
\end{aligned}
$$

\section{ENVIRONMENTAL FEATURES OF CRISES: ANALYSIS OF SELECTED INDICATORS}

Each stage of the economic development of postSoviet Russia had its own sectoral and regional characteristics. The transformational crisis of the mid-1990s was resulted from the transition from a planned to a market economy. The most unfavorable years for almost all industries were 1992, 1993, 1994, and 1998. Almost all changes in natural resource management were autonomous of environmental policy and were largely due to the macroeconomic situation in the country and restructuring of the economy. During this period, first of all, environmental funds decreased, and technological degradation began, which led to additional losses of resources. Unused equipment was physically aging and becoming obsolete; there was a decline in the number of employees, and qualifications of personnel; lack of proper pollution control exacerbated the situation.

The crisis not only failed to improve the environmental situation in the country, but also significantly worsened the problem, turning it into a systemic one. Pollution and natural resource consumption declined much more slowly than GDP and industrial output. As a result, specific atmospheric emissions from all types of sources in relation to GDP increased by $11 \%$; in industry, by $25 \%$; specific water consumption in the economy, by $14 \%$; industrial water consumption, by $64 \%$; the specific volume of polluted wastewater increased by $30 \%$ (Fig. 1).

Structural changes in industry have not helped to reduce pollution. Industries with the highest specific pollution were distinguished by relative economic stability. Pollution was persistent in the energy sector, oil industry, and ferrous and nonferrous metallurgy. There was an unfavorable situation in light, timber, pulp and paper, and woodworking industries.

Nevertheless, for a number of parameters, some industries (e.g., energy and oil refining) managed to achieve an increase in the environmental friendliness of production. Trends towards a reduction in specific air emissions were also observed in the chemical, construction materials, gas, machinery, and food industries.

The sectoral specifics of the crisis also led to regional features. The economic downturn was less severe in regions with export potential (the fuel and energy sector and, partly, metallurgy), as well as in Moscow, where a strong industrial downturn was offset by the outstripping development of the service sector. Only in the Komi Republic, Nenets Autonomous Okrug, and in relatively small depressed regions did the volume of emissions not decrease. Only in Republic of Buryatia and Pskov Oblast, where the Dedovichskaya thermal power plant was commis- 
Table 2. Dynamics of indicators during crisis periods, $\%$ compared to precrisis year

\begin{tabular}{l|c|c|c|c|c}
\hline \multicolumn{1}{c|}{ Indicator } & $1995 / 1991 *$ & 1998 & $2008-2009$ & $2014-2015$ & 2020 \\
\hline GDP & 69 & 95 & $92 / 81 * *$ & 97 & 97 \\
Industrial production & 50 & 95 & $89 / 82$ & $96 / 33$ & $97 / 60$ \\
Air emissions from stationary sources & $62 / 94$ & $97 / 72$ & $95 / 73$ & $94 / 50$ & $98 / 45$ \\
Emissions from vehicles & $103 / 16$ & $104 / 24$ & $100 / 48$ & $103 / 64$ & $97 / 100$ \\
Use of fresh water & $80 / 98$ & $94 / 79$ & $92 / 86$ & $102 / 66$ & $92 / 86$ \\
Use of fresh water in industry & 82 & 96.3 & 89 & $100 / 67$ & $93 / 65$ \\
Discharge of contaminated wastewater & $88 / 73$ & $95 / 73$ & $100 / 84$ & $95 / 64$ & $93 / 74$ \\
Discharge of contaminated industrial wastewater & 71 & 94 & 100 & 99 & 94 \\
Toxic waste volume & n.d. & $120 / 48$ & $90 / 42$ & $98 / 60$ & $90 / 48$ \\
Area of disturbed lands & n.d. & $80 / 69$ & $101 / 90$ & $99 / 83$ & $34 / 100$ \\
\hline
\end{tabular}

* 1995 to $1991 ; * *$ / share of regions in which there was a decrease in the indicator.

sioned, did the volume of water consumption not decrease. The volume of effluents decreased in threefourths of regions; growth continued only in the republics of southern Siberia and the North Caucasus.

The financial crises of 1998 and 2008-2009 were part of global economic crises that affected Russia. In 1998, the decline in industrial production was shortlived, and the subsequent devaluation contributed to import substitution and further growth. The decrease in most pollution parameters occurred at the same rates as GDP and industrial production, by $3-5 \%$. As a result, the specific indicators also increased insignificantly, by $0.3-1.5 \%$, and the specific effluents even decreased by $0.5 \%$. An exception is the volume of toxic waste, which increased by $20 \%$ - a general trend since 1994 (this conclusion was made without taking into account the dynamics of hazard class $\mathrm{V}$ waste: nonhazardous waste, which constitutes the overwhelming value in the total mass of waste). The volume of emissions decreased in three-fourths of the regions, with the exception of oil and gas, capital, and agricultural regions in southern Russia. In general, despite the decline in production compared to the previous crisis, pollution continued to increase in a larger number of regions. The volume of wastewater has increased everywhere, except for regions hosting large thermal power plants and nuclear power plants (Murmansk, Voronezh, Tver, Kostroma, and Sverdlovsk oblasts). The volume of waste has decreased in only $50 \%$ of regions; it has continued to grow in ferrous metallurgy regions.

During the 2008-2009 crisis, the leading factor was again the decline in production, but its positive impact on the environmental situation proved much less than in the 1990s. Air pollution decreased again and then increased; a dependence on the dynamics of production manifested itself, but to a lesser extent than in the years of the previous crisis. It was not possible to reduce the energy capacity of the economy or liquidate the oldest assets in the energy sector, which again led to increased pollution in subsequent years: specific emissions increased by $5 \%$; specific effluents, by $8 \%$; and in industry, by $12 \%$. Specific water consumption remained at the same level, as did waste generation. The area of disturbed lands in industry sharply increased, associated with the development of the extractive industry. The area of forests affected by fires and disease has significantly increased: $73 \%$ by 2008 and another $8 \%$ by 2009 , which most experts associate with the adoption of Russia's new forest code in 2006, which reduced funding for the industry. As in the previous crisis, emissions continued to increase only in one-fifth of regions, mainly the Volga region and republics of the North Caucasus with small volumes of pollution, and depressed regions of Siberia and the Far East, with a high share of heating systems in the pollution structure.

There is no consensus among economists as to the reasons for the 2014-2015 crisis, but the dominant viewpoint is that they are internal: the country has exhausted the possibilities for growth in domestic consumption and has not created new ones within the framework of the existing institutional model and investment climate. Sanctions and the decline in oil prices only accelerated the negative trend. The stagnation of the Russian economy began at the end of 2012. In 2013, industrial production did not grow. As a result, the volume of emissions and wastewater in industry has been gradually decreasing since 2012, while the volume of water consumption, waste generation, and the area of disturbed land began to decline during the crisis. Most environmental indicators decreased by $1-3 \%$.

After 2009, the dependence between the dynamics of production and pollution manifested itself to the minimum extent. A decline in industrial production was noted in almost one-third of regions, and a decline in investment, in half. The volume of emissions decreased in half the regions. The air pollution dynamics was still $85 \%$ determined by three industries, 
the share of each in the volume of emissions is 1.52.5 times higher than in the volume of industrial production. This is the extraction of fuel and energy minerals ( $31 \%$ of the volume of atmospheric emissions); the metallurgical complex (28\%), which is characterized by a steady reduction in emissions with a slight decrease in production and one of the highest specific emissions in industry, as well as production and distribution of electricity, gas, and water $(26 \%$ of emissions). The energy sector is steadily characterized by the highest specific atmospheric emissions and highest degree of dependence of pollution on production volumes (correlation coefficient 0.65 ), which indicates a low level of modernization of the industry. All three industries reduced their emissions by $10-15 \%$ by 2016 versus 2008, while metallurgy and energy also reduced production, and the extraction of fuel and energy minerals ensured economic growth. The most positive trends were characteristic of pulp and paper, chemical, and coke and petroleum production, when, with a noticeable increase in production, a significant reduction in the volume of air pollution was observed.

Road transport has become the leading source of emissions in half the country's regions. The volume of emissions from vehicles has continued to increase, although the growth rate $(1.5 \%)$ was significantly lower than the rate of motorization, which was facilitated by the renewal of the vehicle fleet, improved fuel quality, expansion of the road network, and increased connectivity. During this period, the load of the agrarian complex increased, as well as forest felling, fires, and disease. Specific indicators showed weak growth $(0.4-4 \%)$.

The 2020-2021 crisis associated with the COVID-19 pandemic caused a decrease in GDP and industrial production by $3 \%$. The impact of this crisis on the environmental situation is much less visible, and distortions in statistics contribute to this in many respects. The decrease in water consumption has continued, which in industry has been much faster than in the economy as a whole, as well as in the volume of polluted wastewater. Conversely, the change from growth to reduction took place for indicators dependent on industrial pollution: emissions from stationary sources, area of disturbed land, and volume of waste.

In 2019, the methodology of accounting for emissions from transport and areas of disturbed land was changed, which statistically reduced both indicators by a factor of 3 . One of the main "beneficiaries" of the new methodology was Moscow, the volume of emissions of which, despite significant efforts to develop public transport, a set of measures to prevent the influx of cars into the city center, and build a road network, decreased extremely slowly, amounting to about $940000 \mathrm{t}$ per year. According to the new methodology, the volume of emissions amounted to $330000 \mathrm{t}$.

In contrast all previous crises, all specific parameters (except for specific emissions) decreased, but it is impossible to say that even crises in the modern Russian economy cannot increase specific pollution, since this is largely the effect of changes in the accounting system. Russian statistics do not take into account the volume of emissions from individual housing in cities or dachas and cottages in the suburbs, the emissions of which per unit of burned fuel is an order of magnitude higher than that of centralized heat supply systems. In addition, the relocation of a significant part of the urban population to the suburbs or the presence of quarantine in the private sector has compensated for the reduction in emissions from industrial enterprises.

Thus, different aspects of the environmental situation in regions vary unevenly during periods of crises:

-The volume of emissions is decreasing, particularly strongly in regions with minimum values; pollution in large regions remains almost unchanged.

- The volume of water consumption and area of reclaimed land are reduced during crises almost everywhere, the volume of wastewater gradually decreases throughout the entire period, and in regions with large volumes of waste, it is the fastest; as a result, interregional differences also decrease.

- There are unstable trends in the volume of timber harvesting (a slight decline in 2009 was replaced by a sharp increase in 2016-2017, mainly in large forest regions) and area of disturbed lands, the wavelike changes in which are difficult to explain.

-The volume of waste increases; this indicator is characterized by the highest concentration, which continues to increase.

-The most unstable indicator is the area of forests subjected to fires or death from disease, since it depends on both weather, economic (fire and forestry service funding, availability of reserves for paying for seasonal firefighters, etc.), social (most fires are anthropogenic in origin, resulting from the burning of grass around populated areas), and institutional conditions (forestry regulations of individual territories, administration of work in regions, etc.), as well as other factors.

Thus, in crisis years, the dynamics of various indicators are determined mainly by changes in large regions for each parameter, but in different ways: there is a decline in some indicators and growth in others. Therefore, the change in the territorial structure of pollution during crisis years is multidirectional. In the level of air pollution, waste generation, and load on forests, interregional differences increase during crisis years; in the load on water resources, impact of the agrarian complex, and the area of disturbed lands, they decrease. 

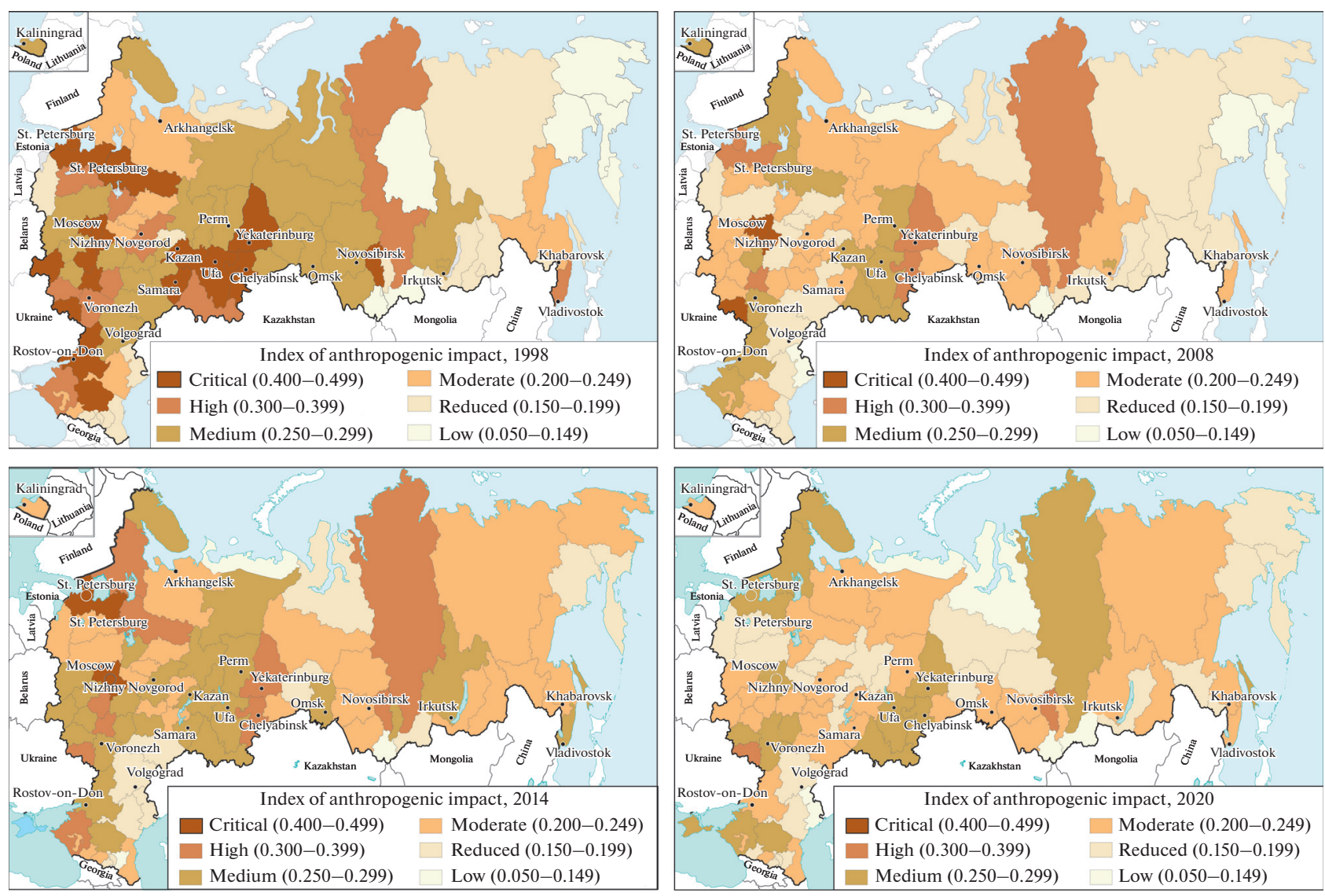

Fig. 2. Integral index of anthropogenic impact in Russian regions, 1998, 2008, 2014, 2020.

\section{INTEGRAL ASSESSMENT \\ OF THE ENVIRONMENTAL SITUATION \\ IN THE REGIONS DURING PERIODS OF CRISES}

In addition to analyzing the impact of key factors, as well as trends in the environmental situation, comprehensive assessment of the transformation of the environmental and economic situation is required. The integral index contains indicators that, to a greater (air, water pollution) or to a lesser (the load on the forestry complex, waste generation) extent depend on the economic dynamics. This is why the integral IAI reacts ambiguously to changes in the economic situation in regions.

In the 1990s, the IAI decreased in almost all regions and the degree of interregional differences decreased markedly by 1998 (from 3.6 to 1.8 times). In $1990,36 \%$ of the country's population lived in the group of regions with a critical AI level, and by 1998, $28 \%$. The stable core of this group consists of regions with a predominant industrial load, where the main AI factors are inherited from the previous era; the impact has become not only powerful, but also continuous (Chelyabinsk, Sverdlovsk, Kemerovo oblasts). In the Moscow agglomeration, the load has shifted very strongly to Moscow Oblast; the growing population concentration has led to significant volumes of wastewater, waste, and the increased impact of vehicles. In 1990 , about $17 \%$ of the country's population lived under high-level AI conditions. By the end of the crisis period, this group decreased by four-fifths. In Krasnodar and Krasnoyarsk krais and Yaroslavl, Nizhny Novgorod, Kursk, and Voronezh oblasts, the conditions have remained (Fig. 2). An average degree of AI was noted in regions with "dirty" industries, which experienced an intense decline; with a predominance of large enterprises in relatively clean industries (Novosibirsk Oblast, Altai Krai, Republic of Mordovia); or regions where the load has shifted (Tyumen Ooblast, Komi Republic). The number of regions with moderate, decreased, and low AI levels grew during the economic downturn of the 1990s but declined again with the onset of economic growth.

In the 2008 crisis, the IAI decreased in 52 regions. Regions with a high level of impact are Krasnoyarsk Krai and Sverdlovsk Oblast; average, Republic of Bashkiria, the Khanty-Mansi Autonomous Okrug, the Komi Republic, and Kemerovo Oblast. The group of regions with a critical load decreased to three (Moscow; Moscow and Belgorod oblasts), but the maximum IAI increased by $2 \%$, and the minimum, by $30 \%$. The level of impact has decreased in many industrial 


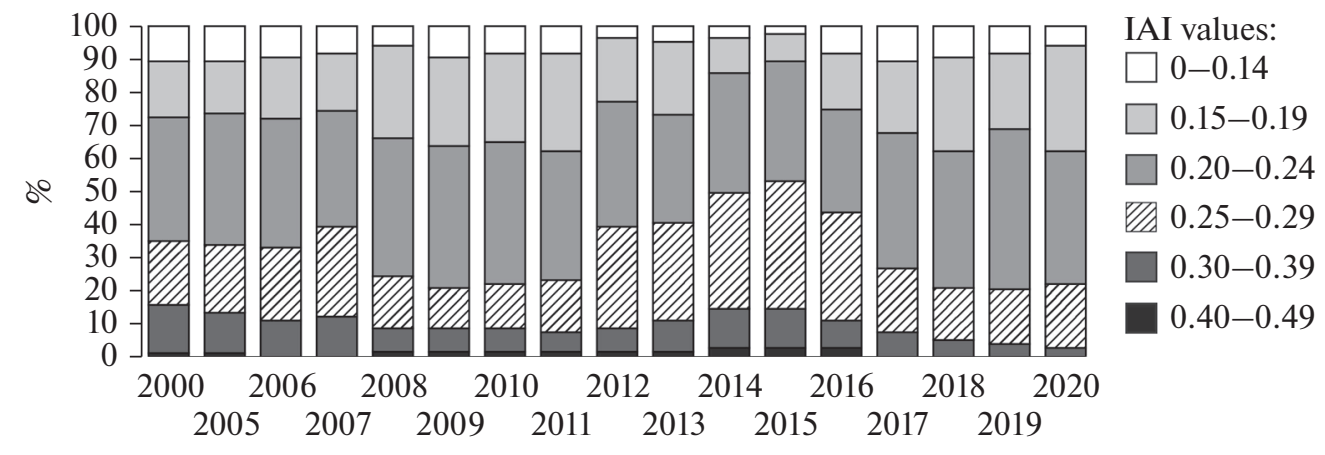

Fig. 3. Regional structure of anthropogenic impact index in 2000-2020 (percentage of regions with a certain index value).

regions previously attributed to the group with the maximum IAI. The group with the average level expanded the most: it includes regions with reduced impact on the atmosphere (Tula, Lipetsk, Vologda oblasts), land resources (the republics of Tatarstan and Bashkortostan), water resources (Krasnodar Krai and Rostov and Orenburg oblasts). The group of regions with the minimum IAI decreased by one-third, whereas the level of impact in Tyumen Oblast and the republics of Tyva and Chechnya increased.

In 2014-2015, Moscow with Moscow Oblast and St. Petersburg with Leningrad Oblast remained in the group of regions with a critical level of impact; in the first case, the IAI decreased versus 2010-2013, and in the second, it increased by 5\%, mainly due to the volume of water consumption and accumulation of solid waste. The group of regions with a high AI level noticeably increased. The basis of this group, as a rule, consisted of industrial regions with a high share of ferrous and nonferrous metallurgy (Kemerovo, Lipetsk, Belgorod, Chelyabinsk, Vologda, and Sverdlovsk oblasts and Krasnoyarsk Krai). In 2014-2015, this group also included agroindustrial regions (Republic of Crimea, Orenburg Oblast, Krasnodar Krai), where the load levels of the agrarian complex have increased largely due to state support. During the crisis, the IAI grew in all regions of this group and in most regions with an average level of AI. The group of regions with an average level of AI increased by one-third due to industrial regions that reduced pollution in the previous period (the Republic of Khakassia; Irkutsk, Smolensk, Yaroslavl oblasts, Stavropol Krai), as well as to regions where the load on the forestry complex increased significantly (Jewish Autonomous Oblast, Sakha Republic (Yakutia), Amur and Tomsk oblasts). Just as in the previous crisis, the group of regions with the lowest level of AI decreased, whereas it grew in the Tyva Republic and Astrakhan Oblast.

In 2020, the territorial structure of AI changed markedly. Only Kemerovo and Belgorod oblasts remained in the group with a high level of AI, since they concentrate a huge part of the country's indus- trial waste. The average level is characteristic both of powerful industrial and agroindustrial regions, which have always constituted the core of this group (republics of Karelia and Bashkortostan; Lipetsk, Orenburg, Murmansk, and Tula oblasts; Krasnodar and Stavropol krais), as well as for regions that have reduced their impacts, including statistically (Moscow Oblast with Moscow, Leningrad Oblast with St. Petersburg, Krasnoyarsk Krai, and Chelyabinsk and Sverdlovsk oblasts). Meanwhile, the group with the lowest IAI level was reduced to five regions (the Yamalo-Nenets and Nenets autonomous okrugs, the Tyva and Altai republics, and Astrakhan Oblast). The remaining regions were equally divided between groups with average and moderate IAI levels. Thus, in 2020, regional differences noticeably decreased (Fig. 3).

\section{CORRELATION BETWEEN CHANGES IN IAI AND DYNAMICS OF ECONOMIC INDICATORS}

The entire variety of scenarios for the dynamics of the impact of material production on the environment can basically be reduced to four types: (1) ecological degradation, when an economic downturn is accompanied by increased environmental pollution; (2) depressive development, when an economic downturn is accompanied by decreased pollution; (3) extensive ecological development, where economic growth is accompanied by increased pollution; (4) balanced development, when economic growth is accompanied by decreased pollution. The scenarios for a change in IAI with respect to GRP have in terms of space a greater mosaic pattern than for individual indicators; the structural dependence coefficients show hardly any dependences. The maximum level of dependence was observed during the crisis period of 1991-1998. In almost all regions, the IAI decreased, but in oil and most depressed regions, it increased; as a result, a degradation scenario developed (Fig. 4).

During the 2008-2009 crisis, the IAI continued to decline in half the regions, forming a mosaic pattern of 

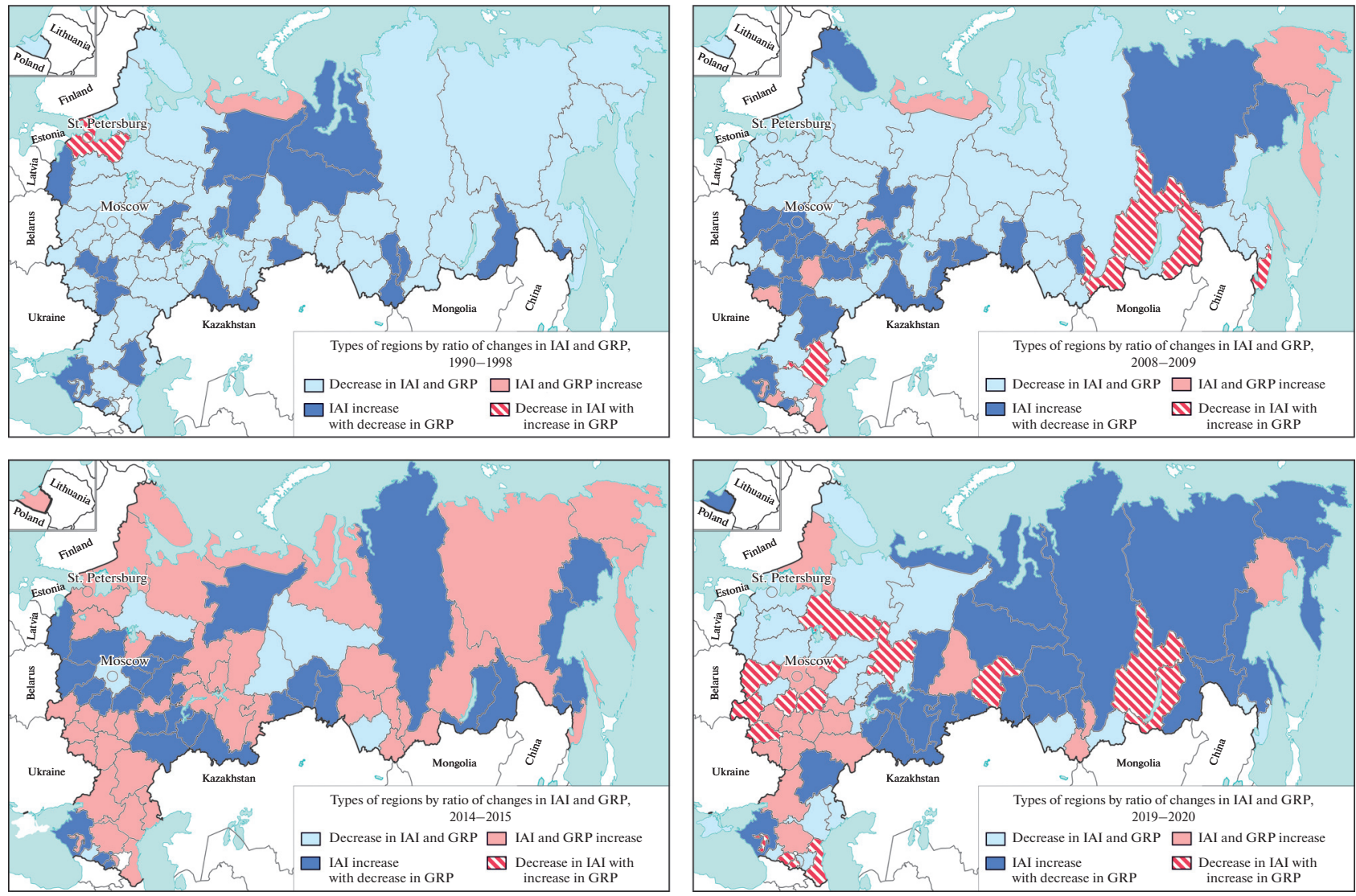

Fig. 4. Ratio of changes in IAI and GRP during crisis periods, \% compared to previous period.

very different scenarios. The greatest decrease was in the volumes of emissions and AI on water sources, forests, and agricultural load. In the Chernozem region, Krasnodar Krai, and regions dominated by the mining industry in the structure of sources of impact (the Sakha Republic and Kemerovo and Magadan oblasts), the IAI continued to increase with decreasing GRP.

In contrast to air pollution and, to a lesser extent, surface water pollution, the integral IAI demonstrates a significantly lower dependence on the dynamics of GRP and industrial production. However, particular indicators also do not correlate with GDP or industrial production: in general, for 1990-2020, a statistically significant correlation coefficient is observed only with the volume of polluted wastewater in industry. However, in 1990-1998, most of the environmental load indicators (except for the volume of toxic waste) are characterized by a high degree of dependence. During the 1999-2008 economic growth period, a high correlation was preserved for the volume of emissions and polluted wastewater in industry, and after 2008 , for the volume of polluted wastewater and waste.

The 2014-2015 crisis affected agrarian regions the least: a small increase in GRP was accompanied by an increase in AI, in most cases at a slower pace. In 2020 versus 2019, the IAI grew, despite the drop in GRP, in most of the eastern regions of the country and the Urals, as well as in Krasnodar Krai. In the Volga region, Chernozem region, Rostov Oblast, and Stavropol Krai, there was a slight increase in IAI with an equally small increase in the volume of industrial production. In the Moscow capital region and Sverdlovsk Oblast, a slight increase in IAI was observed after a rather significant drop in 2019 due to the change in methodology for accounting for vehicle emissions.

In general, during crises, the structure of industry changes faster than the structure of pollution; at the stage of overcoming the crisis, the structure of pollution changes faster, since the most polluting industries grow the fastest. Because in the 2014-2015 and 2020 crises structural changes in industry were not as significant, pollution changed little.

\section{CONCLUSIONS}

In general, in crisis periods in the post-Soviet Russian economy, there has been a gradual decrease in anthropogenic impact. However, this cannot be considered a positive process, since with insufficient modernization, each subsequent stage of growth was accompanied by an increase in pollution. 
Crises have an ambiguous and multidirectional impact on the environmental situation in Russian regions. The common features across all five crises were:

-reduction of industrial pollution (emissions and effluents, to a lesser extent water consumption) and non-crisis-related changes in vehicle emissions, volume of toxic waste, and area of disturbed lands;

- a decrease in pollution at a rate lower than the decline in GDP (GRP) and industrial production and, hence, an increase in the specific parameters of AI marks crisis periods, although in recent years, to a lesser extent;

- the integral IAI depends less on the dynamics of production than individual impact indicators, since the environmental situation is much more complex than the distribution of certain types of pollution;

-in times of crisis, as a rule, the group of regions with a critical AI level is characterized by the greatest stability, while conversely, the group of regions with an insignificant AI level contracts to the greatest extent, since in the most depressed regions, the impact increases in these years.

Differences in the sanitizing role of crises result from their duration, depth, and structural features, as well as the mitigating effect of government support measures:

- the systemic long-term crisis of the 1990s led to a reduction in all indicators, affecting $90 \%$ of the regions; the financial crises of 1998 and 2008-2009 affected $70 \%$ of regions, while the crises of 2014-2015 and 2020 affected $30-60 \%$ of regions;

-the impact of crises on changes in regional structure depends on industry specialization: in the 1990s, the group of regions with a high level of AI decreased to the maximum, which dropped to average and moderate; in 2008-2009 and 2020, the group with a moderate and low level of load increased; and in 20142015, the groups with high and medium AI levels increased to the maximum extent, since against the decelerated decline in industry, the agrarian load began to increase;

-in 1990-1995, 1998, and 2008-2009, most regions reduced pollution either proportionally or more slowly. In the 1990s, environmental degradation was typical of oil and gas regions; in 2008-2009, of sustainable agroindustrial regions. In 2014-2015, due to the widespread growth in IAI, all regions were divided into two groups: extensive growth or environmental degradation. In 2020, the Ural and eastern regions increased the load on the natural environment amid the recession.

Thus, for the country as a whole, the dependence of the pollution level on the level and dynamics of economic development is weakening due to modernization processes in industry, which was the leading source of anthropogenic impact in the Soviet period.
In recent years, this dependence has been minimal. However, with each new crisis, the number of regions increases in which the environmental situation continues to deteriorate, despite the economic downturn. Economic theory requires active government intervention to correct market failures in the environmental sphere, establish special taxes, etc. In a crisis, the state's priority should be to slow down export and raw material development, diversify, and form elements of an innovative economy. Greening of the economy and development of environmentally friendly production and innovation should be supported by the entire range of economic tools: taxes, loans, subsidies, tariffs, duties, and environmental insurance.

\section{CONFLICT OF INTEREST}

The author declares no conflict of interest.

\section{REFERENCES}

Artyukhov, V.V., Zabelin, S.I., and Martynov, A.S., Objective assessment of environment friendly of economic activity: methods and results. Enterprises, regions of Russia, countries of the world, SPERO, 2012, no. 16, pp. 113-142.

Bityukova, V.R., The environmental cost of industrial growth, Ekol. Prom-st' Ross., 2005, no. 2, pp. 8-11.

Bityukova, V.R., Environmental situation in Russian regions in 2016: rating assessment, Ekol. Prom-st' Ross., 2017, vol. 21, no. 12 , pp. 4-11.

https://doi.org/ 10.18412/1816-0395-2017-12-4-11.

Bobylev, S.N. and Zakharov, V.M., Krizis: ekonomika $i$ ekologiya (Crisis: Economy and Ecology), Moscow: Tipografiya LEVKO, Inst. Ustoichivogo Razvit., 2009.

Bobylev, S.N., Minakov, V.S., Solov'eva, S.V., and Tret'yakov, V.V., Ekologo-ekonomicheskii indeks regionov $R F$ (Ecological and Economic Index of the Regions of Russian Federation), Reznichenko, A.Ya., Shvarts, E.A., and Postnov, A.I., Eds., Moscow: WWF Russia, 2012.

Bobylev, S.N., Kudryavtseva, O.V., and Yakovleva, Ye.Yu., Regional priorities of green economy, Econ. Reg., 2015, no. 2 (42), pp. 148-159.

Gómez-Calvet, R., Conesa, D., Gómez-Calvet, A., and Tortosa-Ausina, E., Energy efficiency in the European Union: What can be learned from the joint application of directional distance functions and slacks-based measures? Appl. Energy, 2014, vol. 132, pp. 137-154. https://doi.org/10.1016/j.apenergy.2014.06.053

Grossman, G.M. and Krueger, A.B., Environmental Impacts of a North American Free Trade Agreement: NBER Working Paper 3914, Cambridge, MA: Natl. Bur. Econ. Res., 1991.

Hollander, J.M., The Real Environmental Crisis: Why Poverty, Not Affluence, Is the Environment's Number One Enemy, Berkeley, CA: University of California Press, 2003.

Klyuev, N.N., Environmental consequences of Russian reforms, Probl. Anal. Gos.-Upr. Proekt., 2014, no. 1, pp. $88-100$. 
Lopatnikov, D.L., Ecological transition, Reg. Issled., 2013, no. 3 (41), pp. 4-8.

Lopez, R., The environment as a factor of production: the effects of economic growth and trade liberalization, $J$. Environ. Econ. Manage., 1994, vol. 27, no. 2, pp. 163184.

Rashidi, K., Shabani, A., and Saen, R.F., Using data envelopment analysis for estimating energy saving and undesirable output abatement: a case study in the Organization for Economic Co-Operation and Development (OECD) countries, J. Clean. Prod., 2015, vol. 105, pp. $241-252$.

https://doi.org/10.1016/j.jclepro. 2014.07.083

Shi, G.-M., Bi, J., and Wang, J.-N., Chinese regional industrial energy efficiency evaluation based on a DEA model of fixing non-energy inputs, Energy Policy, 2010, vol. 38, pp. 6172-6179.

https://doi.org/10.1016/j.enpol.2010.06.003

Stiglitz, J.E., Sen, A., and Fitoussi, J.-P., Report by the Commission on the Measurement of Economic Performance and Social Progress, Paris, 2009. http://www.sti- glitz-sen-fitoussi.frwww.stiglitz-senfitoussi.frwww.stiglitzsen-fitoussi.fr. Accessed November 19, 2020.

Wang, K., Yu, S., and Zhang, W., China's regional energy and environmental efficiency: a DEA window analysis based dynamic evaluation, Math. Comput. Model., 2013, vol. 58, pp. 1117-1127.

Wang, Z.-H., Zeng, H.-L., Wei, Y.-M., and Zhang, Y., Regional total factor energy efficiency: an empirical analysis of industrial sector in China, Appl. Energy, 2012, vol. 97, pp. 115-123. https://doi.org/10.1016/j.apenergy.2011.12.071

Where is the Wealth of Nations? Measuring Capital for the 21st Century, Washington, DC: World Bank, 2005. https://openknowledge.worldbank.org/handle/10986/7505. Accessed November 19, 2020.

Yandle, B., Vijayaraghavan, M., and Bhattarai, M., The Environmental Kuznets Curve: A Primer, Bozeman, MT: Property Environ. Res. Center, 2002, pp. 1-24.

Zemtsov, S., Barinova, V., Kidyaeva, V., and Lan'shina, T., Environmental efficiency and sustainable development of Russian regions over twenty years of raw material growth, Ekon. Polit., 2020, vol. 15, no. 2, pp. 18-47. 